\title{
WARS IN $12^{\mathrm{TH}}$ CENTURY CATALONIA. ARISTOCRACY AND POLITICAL LEADERSHIP
}

\author{
MARIA BONET \\ UniversitAT ROVIRA I VIRGILI \\ SPAIN
}

Date of receipt: $4^{\text {th }}$ of October, 2013

Final date of acceptance: $11^{\text {th }}$ of February, 2015

\section{Abstract}

Feudal wars and wars of conquest were characteristic conflicts in Catalonia in the $12^{\text {th }}$ century and led to a consolidation of the aristocratic military and political leaders. Among these, the highest power was the count or the king, who extended his domination and led the process of expansion through such novel formulae as pacification, the formation of armies and pacts with foreign leaders. The counts and the king used military agents from outside the regional aristocratic interests, implemented new military policies and found ideological or legislative resources to support their pre-eminence in military deployment. The rise of the cities, the towns and the defence or occupation of the conquered frontiers contributed to the reformulation of the military system, which broke the almost exclusive hold of the noble families on military activity. However, the members of the latter ruled and fought in regional settings, focussing their military activity on the defending and acquiring patrimony, as well as on establishing their jurisdiction. The concepts of heritagisation, dominating and fighting were assimilated into a single reality, and even became interchangeable. Meanwhile, conquests guided by providence placed the "inevitability" of the conquest, acquisition or "liberation" of al-Andalus on another plane. ${ }^{1}$

\section{KeYwords}

Warfare, Medieval Catalonia, Aristocracy, Military Leadership.

\section{Capitalia Verba}

Bellum, Cathalonia Mediaevalis, Aristocratia, Principes Militares. 


\section{Presentation}

Warfare in Catalonia was transformed in the $12^{\text {th }}$ century with a redefinition of aristocratic relations and military and political leadership. ${ }^{2}$ Until then, links between members of the chivalrous nobility had committed them to military duties and configured the basic structure of political relations. Throughout the century, some notable lineages came to dominate the land to the detriment of other aristocratic families, although they became more dependent on other powers with greater political projection. Thus, the hierarchy was imposed on the new structure of aristocratic relations, which was facilitated by the county or royal authority. ${ }^{3}$ The latter reinforced their leadership by organising and leading the main military activities or conquests in Catalonia, but also the peace. Moreover, other actors, linked to the Church or the cities, participated in the above-mentioned military transformation and the appearance of new levels of government. ${ }^{4}$

War had been an almost exclusive question of the exercise of power by the chivalrous aristocracy with territorial roots. ${ }^{5}$ However, during the $12^{\text {th }}$ century, other dominant groups in society began to define and control this. The covenants and laws, and new ideas about violence also favoured new military and political developments. ${ }^{6}$ The containment of violence, ${ }^{7}$ and the control and administration of newly conquered lands were the key elements of the deployment of emerging

1. This study has been carried out thanks to the research project 'HAR 2009-13225' from the "Ministry of Science and Innovation of the Government of Spain". Some dates are listed for information purposes. 2. Some reference works for defining the new political realities: Salrach, Josep Maria. "El procés de feudalització (segles III-XII)", Història de Catalunya. Barcelona: Edicions 62, 1987: II, 327-398; Bisson, Thomas. The Medieval Crown of Aragon. A Short History. Oxford: Oxford University Press, 1991: 35 and following; Sabaté, Flocel. "Els primers temps: segle XII (1137-1213)", Història de la Corona d'Aragó. Barcelona: edicions 62, 2007: I, 31-123.

3. A similar process took place in the neighbouring kingdom of Aragon: Laliena, Carlos. La formación del estado feudal. Aragón y Navarra en época de Pedro I. Huesca: Colección de Estudios Altoaragoneses, 1996: 247-267; and Utrilla, Juan F. “Los grupos aristocráticos aragoneses en la época de la gran expansión territorial del reino (1076-1134): poder, propiedad y mentalidades", De Toledo a Huesca. Sociedades medievales en transición a finales del siglo XI (1080-1100), Carlos Laliena, Juan F. Utrilla, eds. Saragossa: Institución Fernando el Católico, 1998: 167-197.

4. For the diversification of the forms of military organisation, apart from the traditional feudalvasallistic, see Contamine, Philippe. La guerra en la Edad Media. Barcelona: Editorial Labor, 1984: 84-127.

5. France, John. Western Warfare in the Age of the Crusades, 1000-1300. London-New York: Routledge, 1999: 39-41.

6. Among the ideological novelties about war, the crusading ideology stands out, what some authors call the idea of "holy war". For an overview, Flori, Jean. La guerra santa: la formación de la idea de cruzada en el Occidente cristiano. Granada: Editorial Trotta, 2003; and full attention to the historiography of the theme, Ayala, Carlos de. "Definición de cruzada: estado de la cuestión". Clio y crimen, 6 (2009): 216-242; or related to the reconquest, García Fitz, Francisco. La reconquista. Granada: Editorial Universidad de Granada, 2010: 79-124.

7. Poly, Jean-Pierre; Bournazel, Eric. El cambio feudal (siglos X al XII). Barcelona: Editorial Labor, 1984: 164-177 and its relation with the rise of the crusading movement Cowdrey, Herbert Edward J. "From the Peace of God to the First Crusade", La primera cruzada, novecientos años después: el concilio de Clermont y los orígenes del movimiento cruzado, Luis García-Guijarro, ed. Castelló de la Plana: Castelló d'Impressió, 1997: 51-61. 
powers, which took place in the context of economic growth and changes in the geopolitics of the Iberian Peninsula. ${ }^{8}$ However, military, and to an extent political, leadership remained mainly in the hands of the aristocracy on a territorial level, except in the areas of the New Catalonia, such as the frontiers or the cities. The noble families resisted their loss of military control to other political bodies, such as the count or the king, thus generating conflicts and a certain sharing of fields of influence.

This contribution analyses the characteristics and changes in the Catalan military processes in the $12^{\text {th }}$ century. In this sense, the near monopoly on military activity held by the territorial lords gave way to new actors, and a more complex system of domination arose with renewed political leaderships, like that exercised by the county power. For the purposes of this study, attention is paid to the changes in the typology and formulae in the documentary sources, with the aim of analysing the phenomenon of war through the expressions and registers used in the written records. This, the words and documentary formulae are taken as "signs" of the reality expressed. Thus, over the first third of the $12^{\text {th }}$ century, the relations of power were established through the convenientiae (feudal-vassalistic pacts) and the oaths of loyalty that governed military obligations among the members of the aristocracy. From the mid $12^{\text {th }}$ century, there was an increase in town charters, with regional variables, and a fall in the number of vassalistic pacts. In that phase, much fewer military obligations were demanded than in the early part of the century. Moreover, many beneficiaries of the documents were from non-noble social groups, reflecting the social and political transformations and changes in warfare. In parallel, differences between feudal powers were resolved with letters of pacification in the first third of the century, but these were replaced by judgements from mid century on.

Utterances about military activity have been addressed as the uses of words very clearly reflect the contemporary understanding of the various developments in warfare, as well as its social and political aspects. In this sense, the epigraphs chosen here are faithful to most repeated words in the lexis of the sources and show the main concepts that defined warfare for $12^{\text {th }}$ century men. These were: "guerra" (war) applied to various realities, exercitus (army), pacificare (pacification) as a limitation or ordination of war, military leadership as control of the war and castra (fortifications) as the principal symbol of military domination. The approach deliberately stays away from a statist analysis of medieval politics and warfare and, as a result, from a concept of war of great events or as the result of a certain political strategy has preponderated. ${ }^{9}$ The expansive ephemeris of the County of

8. For the first half of the $12^{\text {th }}$ century in Castile and the peninsular context, Reilly, Bernard. The Kingdom of León-Castilla under King Alfonso VII (1126-1157). Philadelphia: University of Pennsylvania Press, 1998. A concise approach to the $12^{\text {th }}$ century, but attentive to the political and territorial changes, Estepa, Carlos. "El dominio político hispanocristiano en el Occidente peninsular (910-1369)", La historia peninsular en los espacios de frontera: las "extremaduras" históricas y la "transierra" (siglos XI-XV), Francisco García Fitz, Juan Francisco Jiménez, coords. Madrid-Murcia: Sociedad Española de Estudios Medievales-Editum, 2012: 17-45 and 33-37.

9. Without wishing to enter into the debate, for an illustrative example of this kind of history of medieval war as a typical series of battles and confrontations between great political formations, Carey, Bryan 
Barcelona were undoubtedly a milestone in the military and political changes, ones which contributed to the definition of the county political leadership, although the military control of the territory had been and continued to be a major source of power. It was mainly the aristocracy that exercised this military function, although in response to the great military, territorial and economic changes, other agents were added from the mid- $12^{\text {th }}$ century. These pages show how war was a leading, if not the most important, source of power and how it attracted political legitimacy, here following a different approach, one basically opposed to the idea of C. Von Clausewitz. ${ }^{10}$

\section{Wars, army and pacification}

War was the source of the power for the various actors in the political domination, and the transformation of military activity in the $12^{\text {th }}$ century went hand in hand with the changes in political leadership. In the Catalan documentation, the word "guerra" (war) was used to denominate a varied typology of military activities, although it recurrently referred to the feudal conflicts. This use reflects how these military developments were central to the collective "imaginary" of the epoch. In contrast, the use of other terms to refer to larger scale confrontations, such as facere exercitum (form an army) or (acquirere) echoed their special or exceptional assessment of the conquests.

The word guerregare/guerrejare (to fight or make war) generally appeared among the obligations of the vassal, put in writing either in the convenientiae or the oaths of allegiance from the first third of the $12^{\text {th }}$ century. ${ }^{11}$ The vassal agreed to fight for the possessions of the lord and this was expressed in the terms: tenere, defendere et

Todd. Warfare in the Medieval World. Barnsley: Pen and Sword Military, 2009. This does not detract from appreciating the book as a contribution to the study of the tactics and techniques of war. In the Spanish context, the processes of Christian conquest and their political developments remain the main subjects of study in the analysis of warfare and high-medieval policy. Undoubtedly, the larger ones had a major impact, but local or feudal war was a permanent fixture, actively or passively, and crucial in the power relations within feudal societies. Its extent and transformation deserve more attention when describing what war and politics really were in these formations.

10. Following the brilliant approach of John Keegan: War is not the continuation of policy by other means, Keegan, John. A History of Warfare. London: Pimlico, 2004: 3-59, especially 3. The well-known statement by Carl Von Clausewitz sustains that "war is nothing other than the continuation of state policy by other means". Clausewitz, Carl Von. De la Guerra. Barcelona: Editorial Labor, 1976: 320-321.

11. Feudal service was the main formula of recruitment, and even "has served to characterise medieval war as a whole", García Fitz, Francisco. Ejércitos y actividades guerreras en la Edad Media europea. Madrid: Arco Libros, 1998: 18-21. This fits with the statement that medieval warfare was dominated by great proprietors, France, John. Western Warfare...: 53. The spread of the "conveniencias" from the $11^{\text {th }}$ century on has been linked to the need to put an end to feudal violence, or to a feudal conflict in particular, Bonnassie, Pierre. "Les conventions féodales dans la Catalogne du XIè siècle", Les structures sociales de l'Aquitaine, du Languedoc et de l'Espagne au premier age féodale. Paris: Centre National de la Recherche Scientifique, 1969: 169. However, this interpretation contrasts with the fact that the vassal makes commitment to fight to ensure his lord's heritage, as occurred in the $12^{\text {th }}$ century. 
guerreiare (to hold, to defend and to make war). This way, he was obliged to deploy his military "function" to defend his lord's holdings. Guillem de Lluçà pledged to fight to maintain the assets of the diocese of Vic of his lord, the bishop. Other vassals specified that guerram facere (they would fight) for the possessions of the Count of Barcelona, Ramon Berenguer III. ${ }^{12}$ On fewer occasions, the vassal said that adiuvent illos predictos castrum et honore tenere, defendere contra cunctos... qui voluerit tollere... sive guerregare. ${ }^{13}$ In some cases, the lord even retained the right to fight from the enfeoffed castle. ${ }^{14}$

The vassal had to participate in other military-type activities, defined in specific terms, like hostes (the hosts), cabalgades (the rides/raids) and the formation of seguis (retinues/entourages). These commitments were contained in the oaths of allegiance. ${ }^{15}$ Sometimes, the number of knights the vassals had to contribute to

12. Els pergamins de l'Arxiu Comtal de Barcelona, de Ramon Berenguer II a Ramon Berenguer IV, ed. Ignasi Baiges, Gaspar Feliu, Josep Maria Salrach. Barcelona: Fundació Noguera, 2010: II, 801-802 (doc. No. 464) (1115). Agreements according to the formula of "tenere et guerregare" (to have and fight for): Els pergamins de l'Arxiu Comtal de Barcelona...: II, 841-842 (doc. No. 493), 842-843 (doc. No. 494), 843-844 (doc. No. 495) and 844-845 (doc. No. 496); Els pergamins de l'Arxiu Comtal de Barcelona...: II, 850-851 (doc. No. 501) (1118); 852 (doc. No. 502). Sometimes, the defence or the idea of fighting for the lord's heritage was applied to what the lord would have in the future: Colección de documentos inéditos del archivo general de la Corona de Aragón, ed. Próspero de Bofarull. Barcelona: José Eusebio Monfort, 1849: IV, 38 -41 (doc. No. 15) (1134). Other agreements: Els pergamins de l'Arxiu Comtal de Barcelona...: II, 816-817 (doc. No. 476) (1116); 848-849 (doc. No. 499); 902 (doc. No. 539) (1122); 917-918 (doc. No. 545) (1122); Els pergamins de l'Arxiu Comtal de Barcelona...: III, 1046-1048 (doc. No. 628) (1130); $1151-1153$ (doc. No. 694); 1161 (doc. No. 700); $1207-1209$ (doc. No. 732); 1350-1352 (doc. No. 831); 1387-1388 (doc. No. 857); Els pergamins de l'Arxiu Comtal de Barcelona...: IV, 1582-1584 (doc. No. 975) (1154); Cartas de población y franquicia de Cataluña, ed. José María Font Rius. Barcelona-Madrid: Consejo Superior de Investigaciones Científicas, 1969: I, 111-114 (doc. No. 69) (1149). The beneficiaries of the fief would help ibi intrare et exire et guerrejare contra omnes (entering and leaving and/or fighting), Els pergamins de l'Arxiu Comtal de Barcelona...: II, 640-641 (doc. No. 345), or to "ero tibi aiudator a tener et ad aver(help to hold), Els pergamins de l'Arxiu Comtal de Barcelona...: II, 839-840 (doc. No. 492).

13. It was also expressed: "If there were war for the enfeoffed place, I would defend or guard it". The brothers Arnau, Bernat and Ramon Pere fought against those who wanted to seize the castle of El Papiol, of which they held the fief, Els pergamins de l'Arxiu Comtal de Barcelona...:II, 801-802 (doc. No. 464) (1115); the same was done for the castle of Ribes, Colección de documentos inéditos del archivo...: IV, 76-77 (doc. No. 34) (1140). Ramon Pons de Milany swore allegiance for Creixell Castle, and stated to the count, his lord, that he would do everything a vassal should, specifying "military service" and the "wars", Els pergamins de l'Arxiu Comtal de Barcelona...: II, 890-891 (doc. No. 530) (1121). Sometimes, the beneficiary of the custody of a castle, like Ramon Berenguer IV in Peralada, could "intrare et exire et guerreiare" (enter and leave and fight there, Els pergamins de l'Arxiu Comtal de Barcelona...: III, 1093-1094 (doc. No. 653) (1132). Other pacts: Els pergamins de l'Arxiu Comtal de Barcelona...: III, 1380-1381 (doc. No. 853) (1146) y Els pergamins de l'Arxiu Comtal de Barcelona...: II, 678 (doc. No. 373) (1107), Els pergamins de l'Arxiu Comtal de Barcelona...: II 827-828 (doc. No. 483) (1117).

14. Alfonso II. Rey de Aragón, Conde de Barcelona y Marqués de Provenza. Documentos (1162-1196), ed. Ana Isabel Sánchez. Saragossa: Institución Fernando el Católico, 1995: 79-80 (doc. No. 42) (1167).

15. Ramon Miró promised his lord, B. R. of Montcada, in the enfeoffment of Montcada Castle, that the milites autem ipsum fevum tinentes faciant...Berengario hostes et cavalcatas et seguiments et servitia: Els pergamins de l'Arxiu Comtal de Barcelona...: II, 628-629 (doc. No. 335), (1101) and similar: Els pergamins de l'Arxiu Comtal de Barcelona...: II, 642-643 (doc. No. 347) (1104); 662-663 (doc. No. 363) (1106); 709-710 (doc. No. 391) (1109); 882-883 (doc. No. 525), (1120); 890-891 (doc. No. 530), (1121); 924 (doc. No. 550); 709-710 (doc. No. 591). Els pergamins de l'Arxiu Comtal de Barcelona...: III, 1065-1067 (doc. No. 634); 1177-1178 
these actions was stipulated, and this oscillated between two and five. One was even obliged to take twenty knights. ${ }^{16}$ Very occasionally, it was stated that the help was for the host of Hispania -in other words al-Andalus-, that was designated as an extraordinary activity and distinct from the rides or hosts. ${ }^{17}$ The troops provided by the vassals to the military retinues reflected that these were modest formations. The vassals sometimes had to pay for their maintenance, and other times, they received some kind of assistance from the lord, such as the animals. The fulfilment of military obligations by the vassals was reinforced and promoted in the Usatges, the laws compiled by the Count of Barcelona, Ramon Berenguer IV. ${ }^{18}$ At the end of the $12^{\text {th }}$ century, King Alfonso the Chaste, Alfonso II of Aragon, exonerated the inhabitants of certain places from joining the hosts and rides. This change went hand in hand with the increase in his authority and in the context of the progressive relaxation of these obligations by some dependents. ${ }^{19}$

The terms guerregare/guerrejare (make war/fight), servicia (military services), "hostis" (host/army) and "cabalgada" (ride/raid) were fundamentally linked to the duties of the vassal. In the framework of feudal-vassalistic relations, the idea of "war" referred to defending of the lord's possessions in the first third of the $12^{\text {th }}$ century. Moreover, the concepts of "having" or "acquiring" were applied to other warlike developments and thus, warfare was related unequivocally with the act of "heritagisation".

The word war was primordial for designating the struggle between lords in a territory or "feudal war", ${ }^{20}$ which was caused by disputes for possessions, and for territorial or jurisdictional domain. Berenguer Ramon de Castellet and Ramon

(doc. No. 712) (1136); $1193-1194$ (doc. No. 724); 1263-1264 (doc. No. 768); 1304-1305 (doc. No. 799); 1324-1326 (doc. No. 815); 1420-1421 (doc. No. 880). Els pergamins de l'Arxiu Comtal de Barcelona...: IV, 1582-1584 (doc. No. 975) (1145); 1585 -1588 (doc. No. 979) (1154); 1705-1707 (doc. No. 1063) (1160). 16. Ut habeat illis in hostes et cavacaldas III milites, según Arbert Bernat prometió a su señor; Els pergamins de l'Arxiu Comtal de Barcelona...: II, $775-777$ (doc. No. 442) (1113); Els pergamins de l'Arxiu Comtal de Barcelona...: IV, 1598-1599 (doc. No. 991) (1155). Guillem Jofré contributed twenty knights to the count's army, Els pergamins de l'Arxiu Comtal de Barcelona...: II, 854-856 (doc. No. 504) (1118).

17. Els pergamins de l'Arxiu Comtal de Barcelona...: III, 1042-1044 (doc. No. 626) (1129). Et faciam vobis cavalcadas cum meis hominibus et... ostem in Yspaniam cum IIII cabalarios, Els pergamins de l'Arxiu Comtal de Barcelona...: IV, 1776-1777 (doc. No. 1105). The raids into Andalusian lands were part of the expansionist process, García Fitz, Francisco. “Las prácticas guerreras en el Mediterráneo latino (siglos XI al XIII). Cristianos contra musulmanes", Regards croisés sur la guerre sainte, Daniel Baloup, Philippe Josserand, dirs. Toulouse: Casa de Velázquez and Centre National de la Recherche Scientifique, 2006: 323-358 and 335. 18. Los Usatges de Barcelona, ed. Fernando Valls. Barcelona: Promocions i Publicacions de la Universitat de Barcelona, 1984: 82 (number 34): Qui fallierit hostes vel cavalcatas seniore suo; 83 (number 35): Qui viderit senorem suum necesse habere et fallierit; 83 (number 36): Qui solidus est de seniore, and 83 (number 37): Qui seniorem suum in bello vivum relinquerit.

19. Alfonso II. Rey de Aragón, Conde de Barcelona...: 543-545 (doc. No. 410) (1185); 632-638 (doc. No. 479) (1188) and 697-698 (doc. No. 531) (1191). However, King Alfonso continued to call for the hosts and rides in town charters, like the one for Vilafranca, Alfonso II. Rey de Aragón, Conde de Barcelona...: 698-791 (doc. No. 532) (1191).

20. A well-explained example of "feudal" war is the one between the powerful Montcada and Cardona families. See Rodríguez, Francesc. Els vescomtes de Cardona al segle XII. Una història a través dels seus testaments. Lleida: Universitat de Lleida, 2009: 56, 67-68, 71, 109. 
Berenguer III had a "war" in 11 13, as did Pelet and the Count of Pallars Jussa, Bernat Ramon, in $1117 .^{21}$ Pere de Puigverd promised to fight for Pere de Bellvís, his lord, who was at war with the Count of Urgell. ${ }^{22}$ A lord often demanded the involvement of his vassal in a specific war or place, as happened with the castles of Tamarit, Mor or Espluga. ${ }^{23}$ More occasionally, the lord lent military aid to his "vassal" in case of war. The king, Alfonso the Chaste, committed forty knights to the Count of Urgell for the defence of Lleida in 1188, to help him in his war against Ponç de Cabrera. ${ }^{24}$

Beyond the vassalistic obligations, the word "war" was used for the military actions of the lords in their lands as a generic term for regional conflict. Thus, the attack launched by the Count of Barcelona on his vassal, Berenguer Ramon de Castellet, in 1113 was qualified as such. Later, an agreement for pacification was reached as Berenguer Ramon de Castellet could no sufferre guerram comitis. ${ }^{25}$ In the struggle for control of Tarragona, Guillem de Claramunt was accused of having made war on the city, territory and inhabitants of Tarragona in $1168 .{ }^{26}$ Conflicts were sometimes very vicious and could affect all the population, as in Cardona, according to what Ramon Folch related to Pope Alexander III. ${ }^{27}$ The uprising of the Muslims in the Tortosa area was called war, and it was feared that the guerra sarracenorum could paralyse the harvest in $1174 .^{28}$ The use of the term "war" identified the revolt at a regional level with other typical episodes of feudal war, surely given that both attacks affected the lord's power.

Given this evidence, it is seen that the word "war" was used for the feudal territorial conflicts in a profuse and generalised way, showing how war really was to the $12^{\text {th }}$ century. Moreover, it identified the attacks carried out by the Muslims, either

21. Els pergamins de l'Arxiu Comtal de Barcelona...: II, 779-780 (doc. No. 445) and 824-825 (doc. No. 481 ). It was said of Pelet: pels mals et per guerres que ad illo fecit.

22. Diplomatari de Santa Maria de Poblet, ed. Agustí Altisent. Poblet: Abadía de Poblet, 1993: 118 (doc. No. 127) (1150): che io Pere de Puigverd, le'n vala... de ista guerra aut de gerres tro a fi et acord ne sia venguda.

23. In the enfeoffment of Tamarit, the vassal was required to be and fight with three men in the castle because of the possibility of war, El llibre Blanch de Santes Creus, ed. Federico Udina. Barcelona: Consejo Superior de Investigaciones Científicas, 1947: 44 (doc. No. 38) (1134). King Alfonso agreed that the milites of Mor would be by his side in case of "wars" with its lord, Alfonso II. Rey de Aragón, Conde de Barcelona...: 373-375 (doc. No. 249) (1179). Pere de Malacara would fight in Espluga Castle if his lord took part in a "war", Diplomatari de Santa Maria de Poblet...: 125 (doc. No. 137).

24. Alfonso II. Rey de Aragón, Conde de Barcelona...: 640-641 (doc. No. 481), and other agreements, 651652 (doc. No. 490) (1189), 678-679 (doc. No. 515) (1190). In 1190, the king involved himself in favour of the Count and Bishop of Urgell in another feudal war, Alfonso II. Rey de Aragón, Conde de Barcelona...: 672-673, (doc. No. 509). Curiously, he had earlier promised his military "help" to Ponç de Cabrera in his war against the Count of de Urgell, Alfonso II. Rey de Aragón, Conde de Barcelona...: 557-558 (doc. No. 420) (1185).

25. "Resist the count's war". Els pergamins de l'Arxiu Comtal de Barcelona...: II, 779-780 (doc. No. 445).

26. Morera, Emilio. Tarragona Cristiana. Tarragona: Diputació de Tarragona, 1981: I, 464 and Alfonso II. Rey de Aragón, Conde de Barcelona...: 100 (doc. No. 59).

27. Rodríguez, Francesc. Els vescomtes de Cardona...: 65 (1175-1176).

28. El llibre Blanch de Santes Creus: 144 (doc. No. 142) (1170) and El llibre Blanch de Santes Creus: 181 (doc. No. 179) (1174). 
by conquered rebels or raids from Andalusian positions. ${ }^{29}$ Finally, it was also used for larger conflicts, like the struggle between Genoa and Pisa, when King Alfonso II pledged to guerris faciam (make war) in favour of the Genoese. ${ }^{30}$ It also referred to the "war" against King Lobo vel cum aliis sarracenis, undertaken by Alfonso II and the king of Navarre, Sancho the Strong. ${ }^{31}$

The references to attacks against the Muslims from Catalan Christian lands contained singular expressions related to those used to name war. This peculiarity is evidence of the importance and, especially, the exceptionality with which the conquests of al-Andalus were seen. The providential idea of these expeditions was highlighted and it was common to use the expression facere exercitus (formation of an army) to name them. The language echoed a larger reality and the necessity for or "inevitability" of divine protection. ${ }^{32}$ In the plans for offensives into Andalusian lands, formulae were used like quando vero, auxiliante Deo ipsa civitas Tortuosa in potestatem christianorum deveniat, quando Deus dederit Ilerdam in potestate christianorum, Ut Deus reddeat Lerida a cristianis or cum eam nos divina gratia adquirere voluerit et obtinere. ${ }^{33}$ The providential character of the expeditions was added to the idea of "free the lands from the hands of the Muslim", as King Alfonso expressed it in the plan to conquer Majorca. ${ }^{34}$ The actions against the Muslims or other foreign enemies were described as acquirere (to acquire), liberare (to loose) and were the result of facere exercitus (of gathering an army). Among the formulae used to name this type of fight, the word "war" was in a lower position than when used for the

29. Tractats $i$ negociacions diplomàtiques de Catalunya $i$ de la Corona catalanoaragonesa a l'edat mitjana, dirs. Maria Teresa Ferrer, Manuel Riu. Barcelona: Institut d'Estudis Catalans, 2009: I, 300-302 (doc. No. 44) (1128).

30. Alfonso II. Rey de Aragón, Conde de Barcelona...: 575-576 (doc. No. 432) (1186): quod Pisani vel aliqua persona...guerram fecerit Ianue...quamdiu guerra illa duraverit, et illis personis guerris faciam per me et hominos meos.

31. Alfonso II. Rey de Aragón, Conde de Barcelona...: 97-99 (doc. No. 58) (1168). In contrast, the peace with King Lobo would generate resources that would be shared out and that could generate "war" between the two kings, as was warned about.

32. "They will be conquered by God's will", "when God returns us", "when God will give Lleida into the power of the Christians". The conquests were the result of divine will, and this attribution had already been noted in $11^{\text {th }}$ century Catalan documentation, Sabaté, Flocel. "Frontera peninsular e identidad (siglos XI-XII)", Las Cinco Villas aragonesas en la Europa de los siglos XII y XIII. De la frontera natural a las fronteras políticas y socioeconómicas (foralidad y municipalidad), Esteban Sarasa, coord. Saragossa: Institución Fernando el Católico, 2007: 77.

33. Els pergamins de l'Arxiu Comtal de Barcelona...: III, 1185-1186 (doc. No. 718), Cartas de población y franquicia de Cataluña: 104-106 (doc. No. 64), Alfonso II. Rey de Aragón...: 291-292 (doc. No. 207) (1176); Diplomatari de Santa Maria de Poblet...: 92-93 (doc. No. 92) and Quando Deus per misericordiam suam tradiderit Yspaniam in manu christianorum, Diplomatari de Santa Maria de Poblet...: 103-104 (doc. No. 106) and 104 (doc. No. 107). The providential idea was aplied to other notable military campaigns, Els pergamins de l'Arxiu Comtal de Barcelona...: II, 692-693 (doc. No. 380).

34. Alfonso II. Rey de Aragón...: 345-346 (doc. No. 255) (1178): divina providentia gratia de manu paganorum sic in dominio nostro Ihesucristi confidimus, in brevi liberabimus, that in the Catalan counties it was an idea with Carolingian roots, Sabaté, Flocel. "Frontera peninsular e identidad...": 65. The pontifical crusading ideology referred to the neccesity to "recover", "liberate", "return" and affected other discourses orientated towards establishing the legality of the conquest of the Muslim lands, García Fitz, Francisco. La reconquista...: 94-95. 
vassalistic pacts. However, they were also called bellica facta or bellum, as in the Pisan chronicle or Liber Maiolichinus. ${ }^{35}$

The term army described a military contingent with a large number of troops, especially compared with smaller formations that were used for raids, cavalcades or hosts. ${ }^{36}$ The armies were mentioned in important military agreements, and to name the forces deployed against the Muslims. ${ }^{37}$ The Count of Barcelona granted himself the power to gather the troops or the army to attack Hispania, as well as to negotiate peace and war with the Moors, as defended in the legislation in the Usatges. ${ }^{38}$ The administration of war contributed to defining the count's authority over other powers, and attributed to the Muslims, or enemies, a primordial area for the execution of his leadership. ${ }^{39}$ Thus, the king of Sicily had agreed to help the Count of Barcelona with an army and to join his army to attack Andalusian lands. ${ }^{40}$ In the agreements for the conquest of Tortosa in 1146, the Genoese agreed to contribute an "army" to help Ramon Berenguer IV. This would be equipped with war machines given the scale of the siege and the importance of the alliance, as there is no reference to war machines in other agreements.$^{41}$ At the same time, the count declared that he would go with his army. ${ }^{42}$ From the mid $12^{\text {th }}$ century, the phrase facere exercitus (to make an army) was also used as a synonym for the host. ${ }^{43}$ Basically, the count of Barcelona could form these armies, made up of various contingents, such as the Templars. ${ }^{44}$

35. Ricerca Lingüística. "Liber Maiolichinus de gestis pissanorum illustribus". $1^{\text {st }}$ October 2001. Laboratori Linguistica. Università di Pisa. $16^{\text {th }}$ September 2013. <http://dante.di.unipi.it/ricerca/html/lbm.html>: 8 (verse 87), 11 (verse 147), 17 (verse 271), 44 (verse 172), 54 (verse 23), 59 (verse 166), 63 (verse 295), 96 (verse 50), 91 (verse 325): here bellum is used as war.

36. In $10^{\text {th }}$ century Castilian, the exercitus referred to "the set of the magnates with their military entourages" and was a clear precedent for the use of the term seen here, although with the logical chronological and territorial variations, Isla, Amancio. Ejército, sociedad y política en la península Ibérica entre los siglos VII y XI. Madrid: Ministerio de Defensa y Consejo Superior de Investigaciones Científicas, 2010: 192.

37. Expeditions against Andalusian lands were called armies: Alfonso II. Rey de Aragón...: 632-633 (doc. No. 479) (1188).

38. Los Usatges de Barcelona...: 88-89 (numbers 63, 64, 65) and 108 (number 124). The latter stated that the princes, in other words the counts of Barcelona, ibi mandarent hostes quibus irent ad destruendam Yspaniam. The principles of Roman political thought were recuperated, and the emperor and his officials had the right to wage war according to Saint Augustine, France, John. Western Warfare ...: 40.

39. For the analysis of this process, here only referred to in passing, see Bonet, Maria. Organizing Violence: Peace and War in Twelfth Century Catalonia, forthcoming.

40. In servicium Dei et auxilium exercitus ad exercitum Hispaniam, Els pergamins de l'Arxiu Comtal de Barcelona...: III, 1019-1020 (doc. No. 608) and 1020-1021 (doc. No. 609) (1128).

41. Colección de documentos inéditos...: IV, 337-339 (doc. No. 144). There are various references to the army, and some specifically to the county army.

42. Colección de documentos inéditos...: IV, 332-334 (doc. No. 141). The Genovese also committed themselves to a future enterprise to conquer the Balearic Isles.

43. Theoretically, in Tarragona, all knights and men faciant tibi exercitus et cavalcatas to Ramon Berenguer IV, Els pergamins de l'Arxiu Comtal de Barcelona...: III, 1511-1516 (doc. No. 941) (1151).

44. Four knights made a brotherhood with the Temple, joining the county armies "against the Muslims", Els pergamins de l'Arxiu Comtal de Barcelona...: III, 1354-1356 (doc. No. 833) (1145). 
The preparing and carrying out the conquests were extraordinary militarily and politically processes. These meant overcoming the concept of military domain by the modest aristocratic armed groups. Thus, in the run up to the conquest of Lleida in 1147, Count Ramon Berenguer IV encouraged the presence of a hundred men in Almenar, which was a spearhead for the advance on Lleida. The military purpose dominated the resettlement and required a large number of men, with the need for watches (guaitas) and supplies for two days in case of war. ${ }^{45}$ The conquest was coming and the military necessities deferred the payment of the censuses until the fall of the city in favour of the military occupation of the site.

Count Ramon Berenguer IV sometimes rewarded the nobles who had participated in his armies. Pere de Puigverd claimed payment for having taken part in the army that had gone to Lorca with ten knights. He asked for 30 morabatins (Muslim coin) per month per person. However, the Count of Barcelona defended himself replied that he had already paid. ${ }^{46}$ Bernat de Anglesola accused the count of having calling him up for an army that had gone to Aragon, where he had lost many goods. Ramon Berenguer IV denied it. ${ }^{47} \mathrm{He}$ also paid specialist troops, like crossbowmen, although these were few in number. ${ }^{48}$ The count's leadership in these actions was buttressed by his ability to pay for military support beyond personal links. The count's financial power was greater than other lords, to a large extent due to the his access of the resources from the parias, which he dedicated to military activity and domination. So, he promised to pay 1,000 morabatins to the Hospitallers to erect a fortress in Amposta, at the mouth of the Ebro, and 2,000 and 1,000 morabatins to the Count of Urgell before and after the conquest of Lleida, as well as part of the parias. ${ }^{49}$

The military changes came about through the increase in pressure on the frontier territories, with the conquests of the mid $12^{\text {th }}$ century and clearly after the occupation of the lands and cities of the New Catalonia, that required new forms of political and military organisation. In this sense, the Barcelona comital authority delegated the power to maintain peace and to make war to leading people in the conquered or frontiers areas. He had assumed that power and nevertheless he delegated it, even in places where he supposedly had deployed his authority. ${ }^{50}$ Thus, Count Ramon Berenguer III instructed the Count of Pallars to ensure peace and war in 1098 before the unsuccessful campaign in Tortosa. His son, Ramon Berenguer IV did the same with the Count of Montpellier by conceding Tortosa to him in 1136 ,

\footnotetext{
45. Cartas de población y franquicia de Cataluña: 104-106 (doc. No. 64) (1147).

46. Colección de documentos inéditos...: IV, 252-260 (doc. No. 99).

47. Colección de documentos inéditos...: IV, 339-343 (doc. No. 145).

48. Els pergamins de l'Arxiu Comtal de Barcelona...: IV, 1785 (doc. No. 1114).

49. Colección de documentos inéditos...: IV, 126-129 (doc. No. 54).

50. The Count of Barcelona enfeoffed Pujols Rubials to Berenguer Arnal, entrusting him per me facias inde pacem et guerram, Diplomatari de Santa Maria de Poblet...: 93-94, (doc. No. 93) (1139). In 1191, Ramon de Cervera agreed to make peace and war in the castle of Arbesa enfeoffed by the king: Alfonso II. Rey de Aragón...: (doc. No. 538) (1191); Other compromise, Alfonso II. Rey de Aragón...: 557-558 (doc. No. 420) (1185).
} 
and to the Count of Urgell, by giving him Lleida, prior to the fall of either place. ${ }^{51}$ King Alfonso the Chaste ordered Ponç de Lillet faciatis inde pacem et guerram per nos (to make peace and war) when granting him Ascó in 1183 and explicitly against the Moors on giving Alcañiz to the Order of Calatrava in 1179 or Villel to the Holy Redeemer in $1187 .^{52}$ Similarly, Ramón Berenguer III had entrusted the inhabitants of Tarragona to tenere pacem meam et facere guerra. ${ }^{53}$

In contrast, this type of demand did not appear in the town charters of Tortosa and Lleida, but rather loyalty to the count and containment of the feudal violence through the imposition of justice. ${ }^{54}$ The people of Lleida confirmed that they would help the count to retain and hold the city, through a formula similar to the one a vassal pronounced to his lord, but without any reference to military obligation. Pacification was a necessity in the occupied cities. Moreover, since the middle decades of the $12^{\text {th }}$ century, the requirements on a vassal to make war almost disappeared from enfeoffments and oaths of allegiance, coinciding with the consolidation of the peace movement. The royal and comital authorities made the idea of pacification their own, initially pressed by the bishops, and this changed from private places or jurisdictions to all the territory under the authority of the count or king. Alfonso the Chaste imposed a general peace in Catalan territory in 1173, because he claimed it was in the prince's power; bella sedare, pacem stablire. ${ }^{55}$

The pre-eminent position of the Count of Barcelona or the King of Aragon in the administration of peace and war culminated in the establishment of relations of power with peninsular political leaders and others. Ramon Berenguer IV and King Alfonso attributed themselves the power negotiate peace and war in various agreements with the kings of Castile or Navarre. ${ }^{56}$ The Treaty of Tudillén in 1151 between the Count of Barcelona and the King of Castile, Alfonso VII, was defined as a vera pax (lasting peace) and perpetua concordia (perpetual agreement). They divided the territories to be conquered in Al-Andalus, consistent with the fact that these expeditions were carried out under each one's political authority. ${ }^{57}$ Other

51. Els pergamins de l'Arxiu Comtal de Barcelona...: II: 580-581 (doc. No. 296); Colección de documentos inéditos...: IV, 53-54 (doc. No. 22) and Colección de documentos inéditos...: IV, 126-129 (doc. No. 54).

52. Alfonso II. Rey de Aragón...: 503-504 (doc. No. 376); and Alfonso II. Rey de Aragón...: 375-376 (doc. No. 279), 599-601 (doc. No. 453) respectively.

53. "Have their peace and make war" Cartas de población y franquicia de Cataluña: 82-84 (doc. No. 49), 1118.

54. Cartas de población y franquicia de Cataluña: 121-126 (doc. No. 75) (1149) and 129-132 (doc. No. 79) (1150).

55. Gonzalvo, Gener. Les constitucions de pau i treva de Catalunya (segles XI-XIII). Barcelona: Generalitat de Cataluña, 1994: 74-82 (doc. No. 15) and an equivalent proclamation by Peter the Catholic, 114-125 (doc. No. 20) (1200). The king overcame the pacifying tradition attributed to specific situations, and availed himself of the biblical basis in the Christian ideology referring to the monarchy, Bisson, Thomas. The Crisis of the Twelfth Century. Power, Lordship and the Origins of European Government. Princeton: Princeton University Press, 2009: 499-505.

56. Colección de documentos inéditos...: IV, 64-65 (doc. No. 28) (1139), 142-144 (doc. No. 60) (1149), 239 241 (doc. No. 91) (1156), 243-247 (doc. No. 95) (1158), Els pergamins de l'Arxiu Comtal de Barcelona.....:, 1425-1427 (doc. No. 884) (1149) and Alfonso II. Rey de Aragón...: 97-99 (doc. No. 58) (1168).

57. Colección de documentos inéditos...: IV, 168-174 (doc. No. 62). 
agreements or "paces" were reached between the kings of Castile and Aragon. These defined their areas of influence and upgraded their military cooperation against the Moors and the King of Navarre. ${ }^{58}$

The peace and cooperation between Christian leaders created the conditions for the great military enterprises and the distribution of the areas of future conquests. However, the leadership of the Castilian king among the Christian kings and leaders in the Peninsula must be highlighted. This was especially clear in the times of the Emperor Alfonso VII, who, at certain times, obtained the vassalage of García Ramírez of Navarre, Ramon Berenguer IV of Barcelona and Alfonso I of Portugal. Castile's greater military power undoubtedly contributed to a certain preponderance of that kingdom. ${ }^{59}$ Beyond the Peninsula, given their military and political pre-eminence, Ramon Berenguer IV and Alfonso the Chaste continued important diplomatic negotiations with other leading political powers. An example is the military alliance between the Count of Barcelona and the King of England in 1159 against the Count of Toulouse under his Occitanian policy. This led to an unsuccessful siege of Toulouse. ${ }^{60}$

Feudal war continued to be fundamental when settling the authority over the land, although pacification, the resort to justice and especially the new needs generated by the conquests, forced a gradual reduction of violent acts under the emerging political authority. The pacifying measures coexisted with the lords' right to make war in the territory, and the coexistence of these models generated contradictions. One arrangement by King Alfonso aimed at pacifying the roads in Catalonia established a pair of exceptions. Peace on the roads could be affected if there were war between knights or action by the lords whose domains the roads crossed. ${ }^{61}$ Thus, the pacifying legislation assimilated feudal war and the abuses of the lords within their jurisdictions, although it simultaneously sought to pacify the communication routes.

58. Liber Feudorum Maior, ed. Francisco Miquel. Barcelona: Consejo Superior de Investigaciones Científicas, 1945: I, 47-48 (doc. No. 33) (1170) and 48-49 (doc. No. 34), 49-51 (doc. No. 35) or the Treaty of Cazorla (1179); Alfonso II. Rey de Aragón...: 56-58 (doc. No. 4) (1162), 564-569 (doc. No. 426) (1186) and 593-594 (doc. No. 448) (1187). In 1170, the commitment was super et contra omnes christianos, preter regem Anglie, Liber Feudorum Maior: 45-47 (doc. No. 32). From the total of eighteen treaties signed by the Castilian king, Alfonso VIII, eight were with the king of Aragon, Estepa, Carlos. "El reinado de Alfonso VIII. Los horizontes peninsulares", Las Navas de Tolosa (1212-2012). Miradas cruzadas, Patrice Cressier, Vicente Salvatierra, eds. Jaen: Universidad de Jaén, 2014: 211-220; 214-215. The relations between these two monarchies were undoubtedly the most important among the Peninsular Christian powers.

59. Pascua, Esther. Guerra y pacto en el siglo XII. La consolidación de un sistema de reinos en Europa occidental. Madrid: Consejo Superior de Investigaciones Científicas, 1996: 140. This predominance led to intense activity against al-Andalus, not only military, but also political, García Fitz, Francisco. Relaciones políticas y guerra. La experiencia castellano-leonesa frente a el Islam. Siglos XI-XIII. Seville: Universidad de Sevilla, 2002.

60. Benito, Pere. "L'expansió territorial ultrapirenenca de Barcelona i de la Corona d'Aragó: guerra, política i diplomacia", Tractats $i$ negociacions diplomàtiques de Catalunya $i$ de la Corona catalanoaragonesa a l'edat mitjana, Maria Teresa Ferrer, Manuel Riu, dirs. Barcelona: Institut d'Estudis Catalans, 2009: 56-59. 61. Gonzalvo, Gener. Les constitucions de pau i treva...: 15, XI. 


\section{Military and political leadership}

The Catalan aristocracy was reorganised and established its relationship through oaths of allegiance or "conveniencias" in the $12^{\text {th }}$ century. This reinforced the leading lineages, such as the counts of Barcelona or the viscounts of Cardona. ${ }^{62}$ There were other types of agreement, like the so-called "pacification", sometimes identified with a truce, which re-established relations between lords and, significantly, among the Catalan magnates. Moreover, pacification settled differences between members of the territorial aristocracy. ${ }^{63}$ These solutions ended feudal confrontations, often about property or jurisdictions. ${ }^{64}$ The pacification agreements fit into the pacifying movement, which grew from various levels of political power, such as the ecclesiastic, the counts and the cities, with legal and judicial measures.

The leading powers extended their leadership through the processes of pacification, although these usually involved military solutions, as was the case of the Count of Barcelona. Thus, Ramon Berenguer III strengthened his power in the Viscounty of Béziers through "pacification", and promised to help Viscount, Bernat Ató militarily against other leading lords, namely the Count of Toulouse or the King of Aragon and in the reconquest of places like Carcassonne or Rases. ${ }^{65}$ In another pacification in 1127, the count imposed conditions on Ponç II, Count of Empúries, to correct his abuses ${ }^{66}$ His men had committed abuses against the church of Girona, or travellers from the County of Barcelona, like those on their way to the fair in Peralada. Peace was associated with the ecclesiastical patrimony and such specific places as the roads, hence the criminalization of the mentioned acts, which were contrary to peace. The count of Empúries had to pay a fine of 3,000 sueldos to maintain the truce, destroy the castle he had built in Castelló de Empúries, and hand over hostages as a guarantee of compliance. ${ }^{67}$ Ten years later, the counts of Barcelona and Empúries reached another "pacification", after the breaking of truces and mutual accusations. ${ }^{68}$

62. Kosto, Adam. Making Agreements in Medieval Catalonia: Power, Order, and the Written Word, 1000-1200. Cambridge-New York: Cambridge University Press, 2001: 221-222.

63. Various lords agreed a "veram pacem et veram concordiam" (lasting peace and concord) to put an end to the hostilities for Montargull Castle, Els pergamins de l'Arxiu Comtal de Barcelona...: II, 879-880 (doc. No. 523) (1120); Els pergamins de l'Arxiu Comtal de Barcelona...: II: 907-915 (doc. No. 543) (1122); or Galcerà de Sales and Bernat de Romanyà in 1 183, Kosto, Adam. Making Agreements in Medieval Catalonia...: 100.

64. Pacification was defined as the renunciation of goods by Pere Ramon in favour of the Temple, Els pergamins de l'Arxiu Comtal de Barcelona...: IV, 1550-1551 (doc. No. 954), (1153) and another similar one, 1622-1624 (doc. No. 1009) (1157).

65. Els pergamins de l'Arxiu Comtal de Barcelona...: II, $755-757$ (docs. No. 425 and 426), (1112). Among other benefits, the count of Barcelona received the fief of twelve castles.

66. Els pergamins de l'Arxiu Comtal de Barcelona...: II, 978-982 (doc. No. 595) (1127).

67. Els pergamins de l'Arxiu Comtal de Barcelona...: II, 978-982 (doc. No. 595), 982-985 (doc. No. 596), 985 (doc. No. 597) (1127) and Els pergamins de l'Arxiu Comtal de Barcelona...: III, 1004-1005 (doc. No. 599); Colección de documentos inéditos...: IV, 55-57 (doc. No. 23).

68. Els pergamins de l'Arxiu Comtal de Barcelona...: III, 1209-1211 (doc. No. 733). 
Another peace agreement reached by dignitaries from the two counties of Pallars confirmed the necessity for agreements between magnates. The Count of Urgell, Ermengol VI, and the Count of Barcelona guaranteed this agreement, which highlighted their leadership within the Catalan high aristocracy. ${ }^{69}$ Artal II and his brother from the Pallars Sobirà and Bernat Ramon of the Pallars Jussà, who had acted abusively in the neighbouring territories, agreed not to seize anything else and restore their jurisdictions. It seems that the pressure from the King of Aragon contributed to them closing ranks in benefit of peace. ${ }^{70}$

The peaces or truces were not always respected, and with their knights, Viscount Arnau de Castellbó and Arnau de Saga assaulted around twenty-five places in Cerdanya, sacking, robbing, kidnapping and burning in 1188 . The region was under a general peace agreement and the king enforced it again after these events. ${ }^{71}$ Sometimes, and despite the references to queremoniae or armed conflicts, a lord re-established a vassal's authority by giving him new prerogatives or demanding compensation for him for damage caused by the wars. ${ }^{72}$ The formula of pacification gave way to judicial solutions in mid century. In the second half of the $12^{\text {th }}$ century, Count Ramon Berenguer IV settled his differences with leading noble figures in judicial proceedings, as with Guillem Ramon de Montcada, his seneschal, Pere de Puigvert and Bernat de Anglesola to name a few, which was the result of his leadership. ${ }^{73}$ The disputes or claims of the Count or King affected the conquered lands or regions of the March, Tortosa, Lleida and Tarragona, where they had deployed their military authority.

The preparations for and, especially the course of, the conquests in the middle of the century strengthened the leading role of the House of Barcelona. The projects for conquest promoted by the County of Barcelona evolved significantly and radically with the military changes of the time. In a first phase of these plans, the Count of Barcelona entrusted the possible occupation of Tarragona and Tortosa in

69. Els pergamins de l'Arxiu Comtal de Barcelona...: II, 938-941 (doc. No. 563) (1112-1124) and 942 (doc. No. 565). The count of Urgell agreed to help the count of Pallars Jussà if the other count failed to comply with the agreement.

70. Els pergamins de l'Arxiu Comtal de Barcelona...: II, 942 (doc. No. 565) (1112-1124).

71. Bisson, Charles. "The War of the Two Arnaus: A memorial of the Broken Peace in Cerdanya (1188)", Miscel-lània en homenatge al P. Agustí Altisent. Tarragona: Diputació de Tarragona, 1991: $95-107$ and Gonzalvo, Gener. Les constitucions de pau i treva...: 17 (1188).

72. In the pacification between Berenguer Ramon de Castellet and his lord, Ramon Berenguer III, the vassal received incomes in Barcelona, Els pergamins de l'Arxiu Comtal de Barcelona...: II, 779-780 (doc. No. 445) (1113). Sometimes, the vassal reestablished the domain over some patrimonial property that was the subject of controversy, Els pergamins de l'Arxiu Comtal de Barcelona...: III, 1148-1150 (doc. No. 692) (1135). Ramon Berenguer III restituted his vassal Ramon Gausbert to Arraona Castle on "pacifying it", Els pergamins de l'Arxiu Comtal de Barcelona...: II, 788-789 (doc. No. 452), or related 453, 454 and 455 (1113). The vassal sometimes compensated his lord for damage caused by the wars, Els pergamins de l'Arxiu Comtal de Barcelona...: II, 824-825 (doc. No. 481) (1117).

73. Els pergamins de l'Arxiu Comtal de Barcelona...: IV, 1752-1753 (doc. No. 1095), 1753-1760 (doc. No. 1096) and 1760-1764 (doc. No. 1097 Colección de documentos inéditos...: IV, 252-260 (doc. No. 99); Colección de documentos inéditos...: IV, 339-343 (doc. No. 145). Other querimoniae, Els pergamins de l'Arxiu Comtal de Barcelona...: IV, 1693-1696 (doc. No. 1056) (1160). 
the $11^{\text {th }}$ century to other counts. This orientation changed and in the $12^{\text {th }}$ century, the Count of Barcelona pursued various alliances with the Italian maritime powers and such emerging powers as the military orders. The military reinforcement driven by the Count of Barcelona responded to the need to fight the Almoravids, very powerful enemies militarily. Only their fall and the agreement between Ramon Berenguer IV and Ibn Mardanís smoothed the way for the conquests of Tortosa and Lleida. ${ }^{74}$ Given these circumstances, the role of the territorial aristocracy in the conquests was limited and submitted to the Count. So, the two cities were taken with the help of plural armies, war machines, extraordinary military aid, and after sieges that lasted several months. ${ }^{75}$ The conquest of Tortosa (1148) was the main landmark in the military terrain, and provided the count with a level of political authority previously unknown. It was a military deployment without precedents in the Catalan counties, and which occurred in the context of the Second Crusade in the West. In this sense, it involved the presence of forces from the feudal West, like the Genoese navy, and required the use of siege machines. ${ }^{76}$

Ramon Berenguer III had entrusted the conquest of Tortosa to the count of Pallars in 1097. This attempt was unsuccessful, and years later, the Count of Barcelona joined the conquest of the Balearic Isles thanks to an alliance with Pisa. This expedition, with Papal blessing for the Pisans as a crusade, was designed to put an end to the capture of Christians and the harm to trade inflicted by the Muslims on the Pisans from Majorca. According to the Pisan chronicle, the inclusion of the count of Barcelona was accidental. ${ }^{77}$ In it, Ramon Berenguer III was named $d u x$ catalanensis, rector Catalanicus hostes, and together with the count of Empúries, he was called a "Catalan hero".$^{78}$ However, the Count of Empúries was not in Ramon Berenguer III's entourage when the agreement with the Pisans was reached. ${ }^{79}$ They may have led different groups of troops, or at least it confirms the existence of two

74. Guichard, Pierre. Al-Andalus frente a la conquista cristiana. Valencia: Universitat de València, 2001: 134. For the crisis of the Almoravid regime, see pages 116-133.

75. The siege of a city was large-scale military operation, and the sieges of the Andalusian cities were crucial for the occupation of large areas, and finally for the most important victories against Islam in the Peninsula, García, Francisco. "Las prácticas guerreras...": 328-331.

76. For the Second Crusade in the West with such events as the conquests of Lisbon and Tortosa and the expedition to Almería, see Constable, Giles. "The Second Crusade as seen by Contemporaries". Traditio, 9 (1953): 213-279, although this has been a controversial theme. Almería brought together all the crusading slogans, even putting participation in the march on Almeria campaign before participation in overseas campaigns, Baloup, Daniel. "Reconquête et croisade dans la Chronica Adefonsi Imperatoris (ca. 1 150)". Cahiers de Civilisation et Linguistique Hispaniques Médiévales, 25 (2002): 453-480. The Genoese involvement, the "international" presence and the magnitude of the siege in the Genoese version: Caffaro di Rustico. De Captione Almerie et Tortuose. Valencia: Anubar, 1973.

77. Ferrer, Maria Teresa. "Les relacions del comtat de Barcelona i de la Corona catalanoaragonesa amb els estats italians en els segles XI i XII", Tractats $i$ negociacions diplomàtiques de Catalunya $i$ de la Corona catalanoaragonesa a l'edat mitjana, Maria Teresa Ferrer, Manuel Riu, dirs. Barcelona: Institut d'Estudis Catalans, 2009: 162-163 and 289-291 (doc. No. 37).

78. Liber Maiolichinus...: 68 (verse 89), 76 (verse 304), 82 (verse 46), 91 (verse 326).

79. Tractats i negociacions diplomàtiques...: 289-291 (doc. No. 37). 
leaders at the head of the Catalans, who had strained relationship. However, the Count of Barcelona appeared as the main Catalan military leader.

The conquest of Majorca was short-lived. Nevertheless, this event and the plans against Tortosa and Lleida, speaks eloquently of the interests of the County of Barcelona, spurred on by the mercantile interests of Barcelona and its rivalry with the Kingdom of Aragon, to seize the two cities. This was not about occupying any territory and the military objectives had been chosen carefully. Almost certainly, these operations would not have been successful with only the backing of the regional aristocracy, and were carried out with the help of other armies. This context of the need for more troops explains Ramon Berenguer III's request to the king of Sicily for help in 1128 . The latter agreed to supply fifty ships with an "army of help", and in exchange, the count promised half of what they conquered ${ }^{80}$ In the context of collaboration with the Mediterranean naval powers, the count established an agreement with Genoa according to which the Genoese could cross and stay in his lands, and significantly, make "peace and war" on the Muslims. ${ }^{81}$ It seems that Ramón Berenguer III understood that the success of his military operations depended on the technical assistance of the Italians, as finally came about with the participation of the Genoese in the conquest of Tortosa.

The count of Barcelona reached other agreements with foreign powers. In doing so, he partly dispensed with his nobles, and even indirectly curtailed the possible benefits for such magnates as the Count of Urgell. Among these agreements, one between Ramon Berenguer III with the Moorish governor of Lleida, Avifiel, stands out. The governor agreed to hand over various castles in the Lleida area and to become the Count's vassal, with the possibility of receiving honours in Lleida or Barcelona. Furthermore, he offered "to help him" militarily in the move against Tortosa and other Andalusian places, and also to share the parias. These solutions show the curious integration of the Muslim leader into Christian politics. ${ }^{82}$ However, Avifiel must have been preparing his move to Majorca, given that the count agreed to supply him with twenty ships to transport two hundred knights between Christians and Muslims. ${ }^{83}$ The reference reflects the existence of a navy under the control of the Count of Barcelona.

Ramon Berenguer III promised half the lands conquered from the Andalusians to the King of Sicily. Years later, in 1143, his son, Ramon Berenguer IV, granted the Temple a fifth of what they conquered, and then a tenth to the Hospitallers in $1157 .{ }^{84}$

80. Tractats i negociacions diplomàtiques...: 300-302 (doc. No. 44). The agreement was still in the memoirs of King Alfonso, Alfonso II. Rey de Aragón...: 345-346 (doc. No. 255) (1178).

81. Tractats $i$ negociacions diplomàtiques...: 297-298 (doc. No. 41) and more about the links with Genoa, Ferrer, Maria Teresa. "Les relacions del comtat de Barcelona...": 175. A mission was sent to Palermo for this purpose.

82. Els pergamins de l'Arxiu Comtal de Barcelona...: 882-883 (doc. No. 525) (1120): et de Tortosa et de alia Hispania sit illi aiudadors. Et hoc quod alcahaid voluerit habere de his, habeat per manum comitem.

83. Propter hoc convenit predictus comes iamdictus alcahaid ut habeat illi viginti galeas et de gobars tantos ut possit alchaid mittere ducentos cavallos inter christianos et sarracenos et passat illorum ad Maiorcas.

84. Colección de documentos inéditos...: IV, 93-99 (doc. No. 43) and Els pergamins de l'Arxiu Comtal de Barcelona...: IV, 1660-1662 (doc. No. 1028), respectively. 
He had also offered the Genoese a third of what they took. ${ }^{85}$ The count of Barcelona entrusted part of what was conquered to his military reinforcements. This formula of sharing with those involved in the conquests was different from the traditional system used by counts and other military leaders of enfeoffing places before their conquest. Furthermore, the Count chose powers and institutions that were not linked to the local interests, and did so in detriment to the region's aristocracies. The donations to the Temple, and even to the Hospital, arose as compensation for the loss of political rights in the kingdom of Aragon. However, the orders soon complied with the objective of fighting the Moors. Thus, the military institutes were involved as agents of the Count's or King's authority in conquests, as well as in the occupation of conquered lands. Their specific mission of fighting against the Muslims favoured their inclusion in the expeditions, which was consistent with their special consideration. ${ }^{86}$ In this sense, the crusading identity was also claimed as a sign of distinction of the Count's power and especially, his military charisma. In 1113, Ramon Berenguer III had taken the cross from the archbishop of Pisa, and his son, Ramon Berenguer IV, expressed his crusading mission in the resolution imposed on the Templars in $1143 .{ }^{87}$

The idea of specialization or military specificity grew and this encouraged the involvement of military officers free of family or patrimonial interests whether these were from the military orders, or the Pisan, Sicilian or Genoese navies. The archbishop of Tarragona had a similar intention when he entrusted the occupation of Tarragona to a Norman knight. This way, the prelate dispensed with the consolidated lineages in the surroundings of the city, like the Claramunt, who soon became enemies. Then he instructed the Norman vassal to fight to defend Christianity, with clear crusading resonances, and in so doing, the pact going beyond a mere feudal-vassalistic agreement was forged. ${ }^{88}$ There was the necessity to achieve greater military efficacy, and in turn, to restrict the activity of the lineages settled in the area. This happened in territories like the wilāyah of Siurana. After it fell, the Count led the repopulation and sidelined the Cervera family, who prevailed over the neighbouring region and had participated in the conquest of Siurana itself (1153-1154). ${ }^{89}$

The Count of Barcelona used various policies to involve the Catalan nobles in the conquests. These were affirming his leadership in these initiatives, promoting

85. Tractats i negociacions diplomàtiques...: 309-314 (doc. No. 51) (around 1146).

86. Ad exercendum officium milicie in regione Ispanie contra sarracenos, Colección de documentos inéditos...: IV, 93-99 (doc. No. 43).

87. It was said about the count: sanctissime crucis signum a Petro reverentissimo Pisanensi...archiepiscopo...suo humero susceperat, Tractats i negociacions diplomàtiques...: 300-302 (doc. No. 44) and Colección de documentos inéditos...: IV, 93-99 (doc. No. 43). This identification of the Count with the crusading movement was reinforced from the papacy shortly before and somewhat after the conquest of Tortosa, Bonet, Maria. Organizing Violence...

88. In defensionem Chistianitatis militiam exerceas, Cartas de población y franquicia de Cataluña: 87-89 (doc. No. 51) (1129).

89. Bonet, Maria. “Las dependencias personales y las prestaciones económicas en la expansión feudal en la Cataluña Nueva". Hispania, 66/223 (2006): 425-482; 437-477. 
the family lines close to the Count and impeding the promotion of lineages. He also reached agreements to ensure his military pre-eminence and link some Catalan magnates to the main enterprises. He sometimes managed to have some recognise him as the lord of the regions of Lleida or Tortosa once they fell, as the hostile Count of Empúries did. Furthermore, in the 1130 covenant, Ponç II of Empúries agreed to help him militarily. However, the Count of Barcelona had no intention of benefiting him, as he did with other members of the aristocracy who were loyal to him. Ponç was not a member of his circles, and they both left behind a series of conflicts, which escalated again later. ${ }^{90}$ In the "conveniencias" in the first half of the $12^{\text {th }}$ century, the Catalan nobles confirmed their links to the Count of Barcelona. They expressed their commitment to help him to conserve the parias he received from Andalusian lands, and even the lands he might conquer. It was a different formula to the characteristic feudal-vassalistic pacts and in it, the vassals recognised the Count's power to receive the parias and administer the conquered lands. ${ }^{91}$

The Count of Barcelona reached specific agreements with lords who were important for his military campaigns against Tortosa and Lleida, and his leadership prevailed among his magnates. Ramon Berenguer IV conceded the city and fortifications of Tortosa to William of Montpellier as a fief in 1136, in exchange for William's military involvement under his command..$^{92}$ Ten years later, he granted his seneschal, Guillem Ramon de Montcada, a third of Tortosa and the Balearic Isles. ${ }^{93}$ However, Tortosa only fell thanks to the incorporation of contingents from far-off places and, especially, Genoese naval and military support. Ramon Berenguer IV formalised an agreement with Genoa for the conquest of Tortosa and the Balearic Isles in 1146, just when the Italian city reached another arrangement with the King of Castile to conquer Almería. ${ }^{94}$ In the pact, the Count of Barcelona referred to the one between the Genoese and Alfonso VII, and stipulated that they would attack

\footnotetext{
90. Els pergamins de l'Arxiu Comtal de Barcelona...: III, 1046-1048 (doc. No. 628) (1130): Poncius comes... Raimundo comiti... adiutor sit... honore... de ipsa Fraga et de Lerida... ad Tortuosam. De istis civitatibus.. comes Barchinonensis habet... predictus Poncius.. sit... fidelis adiutor ad tenere et aprehendere, conquirere atque defendere. 91. Els pergamins de l'Arxiu Comtal de Barcelona...: II, 644-645 (doc. No. 349) (1 104); Els pergamins de l'Arxiu Comtal de Barcelona...: II, (doc. No. 363) (1106); Els pergamins de l'Arxiu Comtal de Barcelona...: II, 726-729 (doc. No. 402) and 729-731 (doc. No. 403) (1110): about the parias: de ipsas paries de Hispania quas hodie habes...sunt tibi et...adhuc adquisiturus est, Deo dante, Els pergamins de l'Arxiu Comtal de Barcelona.... II, $740-741$ (doc. No. 413) (1111); Els pergamins de l'Arxiu Comtal de Barcelona...: II, 968-969 (doc. No. 587) (1126). Joan de Sanmartí swore to the count that he would help to defend everything he had or would have in Yspania, Els pergamins de l'Arxiu Comtal de Barcelona...: II, 844-845 (doc. No. 496). Guerau Alemany de Cervelló swore allegiance to the count in the terms: Et convenit quod adiuet eum fideliter tenere omnem honorem suum non solum in christianitate sed etiam in Ispania, Els pergamins de l'Arxiu Comtal de Barcelona...: III, 1352-1353 (doc. No. 832) (1145). A vassal of the count, Deusdat, had to go to collect the parias under the orders of the Count of Barcelona, who granted him a tenth and goods in Valencia quando Deus dederit ei de terris Ispanie, Els pergamins de l'Arxiu Comtal de Barcelona...: III, $1155-1157$ (doc. No. 696) (1136).

92. Els pergamins de l'Arxiu Comtal de Barcelona...: III, 1185-1186 (doc. No. 718) (1136).

93. Els pergamins de l'Arxiu Comtal de Barcelona...: III, 1379-1380 (doc. No. 852).

94. Tractats $i$ negociacions diplomàtiques...: 309-318 (docs. 51 and 52). The agreement would have come a month after the one with Montcada, which reflects that the Count's solutions with the seneschal and the Genoese were complementary, a third for each of the three parties.
} 
Tortosa and the Balearic Isles on their return from Almería. It was, in a way, a threeway agreement.

These agreements allowed the Genoese to maintain colonies to consolidate their trade in the Western Mediterranean, and in exchange, they guaranteed the leadership of the Peninsula's military leaders. ${ }^{95}$ The comital alliance with the Genoese had the backing of the leading figures of the Catalan nobility, who recognised the agreements and the count's command. The Genoese placed themselves under his authority, as they only besieged cities from the Ebro to Almería with his permission, and the Count would receive two thirds of everything seized. At the end of the contest, after the decisive participation of the Genoese, the city was divided into three, and the Count strengthened his position through the formula of partition and incorporating loyal people at the head of the city, such as the seneschal Montcada and the Templars. Finally, he acquired the Genoese part, which reflects how the count's military leadership favoured his political domination of the conquered lands. ${ }^{96}$

Before the fall of Lleida, the Count of Urgell had taken up tactical positions around the city of Lleida with the aim of conquering it. This approach took place through enfeoffments in the Pla d'Urgell or places near Lleida. With these, his vassals were involved in the military tasks, or simply established his authority by renewing ties with prominent vassal lords. The military build-up in the region was fuelled by powerful lords in the years before the conquest, and significantly by Ermengol VI of Urgell. So, for example, the Count granted a "turrim destructam" (destroyed tower) in Bellcaire, and the beneficiaries were given the obligation to rebuild it. As an extraordinary situation, they were allowed to enjoy an income to finance the defence against the Muslims during the construction of the fortification, or until the fall of Lleida. ${ }^{97}$

In the run up to the conquest of Lleida, the Count of Barcelona established a vassalistic pact with the Count of Urgell that gave him the military leadership of the operation and the domination of the city. Through that agreement and after the conquest, Ramon Berenguer IV limited of Ermengol VI's authority, because it converted the region, which had been the area of expansion of the County of Urgell, into a conquest of Barcelona. ${ }^{98}$ The Count of Barcelona identified the conquests as territories under his authority and with a differentiated, military and frontier

\footnotetext{
95. The mercantile and naval interests of the Genoese in the western Mediterranean clashed with their Muslim enemies, who threatened their trade links with Provence and Catalonia. Moreover, Pisa, rival par excellence of Ligurian interests, had reached a trade agrement with Almería in 1133. For a series of Genoese attacks in North Africa and Almería combined with political pacts like the ones referred or with Marseilles, Antibes and other cities, Montesano, Marina. "La guerra dei genovesi nel Mediterraneo: da Gerusalemme alla presa di Almeria e Tortosa (secc. XI-XIII)", Regards croisés sur la guerre sainte, Daniel Baloup, Philippe Josserand, dirs. Toulouse: Casa de Velázquez and Centre National de la Recherche Scientifique, 2006: 255-275; 272 and 273. This is the context in which the pact with the count of Barcelona should be seen.

96. Els pergamins de l'Arxiu Comtal de Barcelona...: IV, 1563-1564 (doc. No. 963), 1564-1566 (doc. No. 964) (1153).

97. Cartas de población y franquicia de Cataluña: 93-94 (doc. No. 56).

98. Colección de documentos inéditos...: IV, 126-129 (doc. No. 54).
} 
character, which translated into his entitlement as Marquis of Lleida and Tortosa, titles that might had military connotations as well as an honourable sense, especially because at the same time the traditional counties were getting obsolescence ${ }^{99}$. The asymmetric reality of the relation between the two counts was shown in a series of compensations that the Barcelona leader granted to the Count of Urgell. The great military events responded to the interests and objectives set from the County of Barcelona. The conquest of Tortosa, the most difficult, was the first, given that it was the most necessary and the most interesting in economic terms. Lleida would come later, and finally Siurana. The plan to conquer Majorca was present throughout the century, as was the one for Valencia at some moments, as King Alfonso the Chaste warned in 1176 . This series of victories contrasts with the difficulties that the Count of Barcelona had to impose himself in territories where local lords prevailed, sometimes maintaining armed conflicts and others simply dominating.

Some regional lineages sought alliances or vassalistic allegiances and consolidated their power, also prior to the conquests. This happened in the Conca de Barberà, the Baixa Segarra, the Garrigas, and even in the Camp de Tarragona. The new security conditions derived from the taking of Tortosa and Lleida changed this panorama, or at least favoured divergences with the new political agents. These differences were revealed, for example, in the litigation by Bernat and Berenguer de Anglesola against Count Ramon Berenguer IV. The Anglesola claimed the domains they had been occupying between Anglesola and Lleida, although the Count defended himself by claiming that he had acquired them from the Muslims with the conquest of Lleida. He added that neither his grandfather, as the Anglesola claimed, nor he himself had granted these honours to them. In light of this news, seen as the prelude to the conquest, the Christian domains in the vicinity of Lleida were extended, but finally the Count of Barcelona was vindicated and validated these as his acquisitions to Muslims. ${ }^{100}$ The authority of the Count or King did not always prevail, and they came to recognise that of lords of the territory who had been refractory to their authority, such as the Cambrils lineage.

Despite the difficulties, royal and county leadership over the territorial aristocracy was reinforced thanks to military developments. One must ask how the Count and King achieved their leadership. They reached this pre-eminence through agreements with other kings in the Peninsula, the control of the parias with the Moors, the pacts with the Italian powers, the reception of the crusading idea and the settlement of the "Battler"'s will, the administration and extension of the pacifying process, the submission of some important magnates, the renewal of many loyalties, the rise of the regular orders, especially the military ones, and also and especially, the consummation of their military leadership. Furthermore, the political hierarchy of the epoch, especially when the Count of Barcelona was also king, granted him the condition of military leader par excellence. Count Ramon Berenguer IV, especially after the conquest of Tortosa, and King Alfonso the Chaste participated in, or led,

99. Sabaté, Flocel. El territori de la Catalunya Medieval. Barcelona: Fundació Salvador Vives Casajuana, 1997: 30-41.

100. Els pergamins de l'Arxiu Comtal de Barcelona...: 1760-1764 (doc. No. 1097) (1153-1162). 
expeditions of conquest or other military endeavours year after year, except for a brief halt after the inrush of the Almohads. Their military leadership was made explicit through a significant continuity of the periods of warfare.

\section{Fortifications and military policy}

The fortifications were the axis of warfare in $12^{\text {th }}$-century Catalonia, following the systematic military system in the feudal West based, above all, on siege warfare. ${ }^{101}$ Thus, the fortresses or fortified towns were the centres of political authority in the territory. ${ }^{102}$ The lords based their domination of a region on their castles and the enfeoffed ones. In addition, the comital power sought to achieve control of the fortifications, although the results were often mediocre. A principal element of the relation agreed between lords was the donation of the fief or castle to the vassal. Furthermore, these feudal-vassalistic agreements contained provisions for military services and the links that ruled the hierarchic structure of power. This way, the vassal specified the castles for which he owed allegiance through his oath. ${ }^{103}$ Moreover, on occasions, he enumerated the lord's castles when he promised to defend all his "honours". ${ }^{104}$

Access to the castles by the lords was central to the relations of power, as it reinforced their authority over that of the vassal. In this sense, the lord reserved the right to stay, estatica, in the fortifications, and claimed it in the enfeoffments,

101. Contamine, Philippe. La guerra en la Edad Media...: 127-128, García, Francisco. Ejércitos y actividades guerreras...: 50-56. The great majority of confrontations in war at that time were sieges, Bradbury, Jim. The Medieval Siege. Woodbridge-Suffolk: Boydel, 1992: 71, although J. France qualified that rather generalised idea that "battles were relativley rare", France, John. Western Warfare...: 150. The building of fortifications increased all over the feudal West in the High Middle Ages, and the development of defences in the lands of the Eastern crusades was also very notable, Keegan, John. A History of Warface...: 141-142 and Chevdden, Paul, E. "Fortifications and the Development of Defensive Planning during the Crusade Period", The Circle of War in the Middle Ages, Donald Kagay, Andrew Villalon, eds. Woodbridge: The Boydell Press, 1999: 33-43.

102. Ferrer, Maria Teresa. "La organización militar en Cataluña en la Edad Media". Revista de Historia Militar, 45 (2001): 120-139.

103. Kosto, Adam. Making Agreements in Medieval Catalonia...: 85-86. Guillem Jordà I; Galcerà Miró; Berenguer Ecard; Dalmau Bernat; Pere Ramon detailed the castles for which he owed allegiance to the Count of Cerdanya, Els pergamins de l'Arxiu Comtal de Barcelona...: II, 710-711 (doc. No. 392), $712-713$ (doc. No. 393), 714-715 (doc. No. 394), 718-719 (doc. No. 396), (1095-1109) respectively, Els pergamins de l'Arxiu Comtal de Barcelona...: II, 726-729 (doc. No. 402), 740-741 (doc. No. 413) (1111), $781-782$ (doc. No. 446) (1113), 923-924 (doc. No. 549) (1123), Colección de documentos inéditos...: IV, 67-69 (doc. No. 30) (1139). Also in the convenaintiae, Els pergamins de l'Arxiu Comtal de Barcelona...: II, $732-733$ (doc. No. 405) (1110), 744-745 (doc. No. 416) (1111), 750-751 (doc. No. 421 ) (1112), 917-918 (doc. No. 545) (1122), 1009-1010 (doc. No. 602), 1013-1014 (doc. No. 604). Sometimes, the vassal gave the "power" over his castles to the lord with whom he acquired the vassalistic link, Els pergamins de l'Arxiu Comtal de Barcelona...: II, 656-660 (doc. No. 361) (1097-1105).

104. Els pergamins de l'Arxiu Comtal de Barcelona...: II, $663-664$ (doc. No. 364) (1106); $683-688$ (doc. No. 376) (1107); 917-918 (doc. No. 545); Colección de documentos inéditos...: IV, 58-41 (doc. No. 15) (1134). 
especially in the first half of the $12^{\text {th }}$ century. ${ }^{105}$ The right to stay, normally with lodging or forfait, was detailed in some county diplomas, in Cerdanya, Pallars, Urgell or Barcelona, and often appears in those signed with the viscounts of these counties in the early decades of the century. ${ }^{106}$ This requirement was justified by the fact that "Potestatem de suo castro... nullo homo contradictat homo seniori suo", as indicated in the legislation in the Usatges. ${ }^{107}$ In fact, the expression "have power" in the castle was used as a synonym of the right to stay. ${ }^{108}$ This explains that the lords intervened in the castles through the figure of the castellan, who they chose directly or had to approve if this person were chosen by the vassal. ${ }^{109}$

The construction of fortresses was the result of the exercise of authority in a region and also a bore witness to this. Thus, after disputes over the control of an area, fortifications were destroyed in accordance with the "authority" acquired by the winner of the dispute. The Count of Barcelona obliged the Count of Empúries to destroy fortresses, like the above-mentioned one in Castelló d'Empúries, and the castles of Charmezo and Rocabertí in 1138. ${ }^{110}$ Furthermore, Ponç II Hug of Empúries agreed not to raise any fortifications in the bishopric of Girona and Roussillon. ${ }^{11}$ Similarly, the Count of Urgell agreed with some lords of the region on the destruction of the fortifications raised in Meià, and not to build others. ${ }^{112}$ The right to fortify was identified with the exercise of authority in a territory. However, the political domination of the Count meant he claimed control over

105. It was specified in feudal-vasallaistic pacts, thus Lord Ponç Bernat retinet... sua estatica in ipsum castrum, Diplomatari de Santa Maria de Poblet: 110-111 (doc. No. 117) (1149). Even the right to abode affected the castellan of the lord and the lord, Els pergamins de l'Arxiu Comtal de Barcelona...: III, 1297-1299 (doc. No. 795) (1142); Alfonso II. Rey de Aragón...: 288-290 (doc. No. 205) (1176).

106. The vassal gave the "potestad" (power) and abode of the castles to the Count of Cerdanya, Els pergamins de l'Arxiu Comtal de Barcelona...: II, 712-713 (doc. No. 393). Other oaths of allegiance with recognition of abode for the lord: 662-663 (doc. No. 363) (1106), 663-664 (doc. No. 364) (1106), 667668 (doc. No. 366) (1106); Els pergamins de l'Arxiu Comtal de Barcelona...: II, 888-889 (doc. No. 529) (1121); 890-891 (doc. No. 530) (1121); 964-965 (doc. No. 585) (1126), Els pergamins de l'Arxiu Comtal de Barcelona...: III, 1007-1008 (doc. No. 601) or in convenientia, 1075-1076 (doc. No. 643) (1130); 11501151 (doc. No. 693) (1136). Bernat Berenguer allowed his lord, Ramon Renard, to stay in the fief and moreover recognised the "potestad" of the lord's lord, the Count of Barcelona, Els pergamins de l'Arxiu Comtal de Barcelona...: II, 924 (doc. No. 550) (1123). King Alfonso reserved the "potestad" of consigned castles, Alfonso II. Rey de Aragón...: 96-97 (doc. No. 57) (1168).

107. "The power over the castles should be returned their lords", Los Usatges de Barcelona...: 84 (number 42 ). 108. Els pergamins de l'Arxiu Comtal de Barcelona...: II, 667-668 (doc. No. 366) (1106). The vassal was asked to "diese la potestad" (give him the power), Alfonso II. Rey de Aragón...: 261-262 (doc. No. 181) (1174), Alfonso II. Rey de Aragón...: 627-628 (doc. No. 474) (1188), Alfonso II. Rey de Aragón...: 660-661 (doc. No. 498) (1189). On the right of "postat", Ferrer, Maria Teresa. "La organización militar...": 139-144.

109. Els pergamins de l'Arxiu Comtal de Barcelona...: III, 1280 (doc. No. 780); 1424-1425 (doc. No. 883) (1149); Alfonso II. Rey de Aragón...: 174 (doc. No. 110) (1171); Els pergamins de l'Arxiu Comtal de Barcelona.... IV, 1585-1588 (doc. No. 979) (1154).

110. Els pergamins de l'Arxiu Comtal de Barcelona...: II, 978-982 (doc. No. 595) (1127) and Els pergamins de l'Arxiu Comtal de Barcelona...: III, 1209-1211 (doc. No. 733) (1138). The count's steward committed himself to destroy "edificios"(buildings) built in the Monte de San Lorenzo, Colección de documentos inéditos...: IV, 42-44 (doc. No. 17) (1136).

111. Els pergamins de l'Arxiu Comtal de Barcelona...: II, 599 (c. 1127).

112. Diplomatari de Santa Maria de Poblet...: 81 (doc. No. 79) (1132). 
the fortifications. The Count of Barcelona reserved the right to "give permission" for the building of fortifications, monasteries or churches, in a plan that was more theoretical than effective. ${ }^{113}$ Thus, a sentence went against the building of castle by Galcerà de Salses sine litentia comitis, and appealed to the "usatge" to impose the wishes of Count Ramon Berenguer IV. ${ }^{114}$

The consolidation of castles and lineages in regions neighbouring those that were going to be conquered were vital for later military developments, such as in the areas of Lleida or Siurana. Indeed, the erection, reconstruction and enfeoffment of fortresses in the regions near the city of Lleida was promoted years before its conquest. The military scheme of establishing counter-castles before enemy strongholds or cities was followed. These were safe bases from which to launch attacks to wear down the enemy positions before their conquest. ${ }^{115}$ Some enfeoffments mention the fortress having to be built or rebuilt, for example in Bellester, Pujols Rubiols, Tarrés, or report that it was destroyed, with the aim of rebuilding or repairing it. ${ }^{116}$ Lords interested in conquest, like the Count of Urgell, consolidated their authority through the enfeoffment of castles that were in the hands of other lords, as he did with Ramon Arnal, who had fortified Almenara. The Count of Urgell was aware of the position of some fortifications infra finibus marchiarum, and the need to establish vassalistic relations in these places to reinforce his authority. ${ }^{117}$ The requirements to lend military duty were frequent in the enfeoffments or in donations in the Marches of the Counties of Urgell and Barcelona in the two decades prior to the conquests of Lleida and Siurana. ${ }^{118}$ The "castralisation" or militarisation of the region responded to a defensive programme, but military reinforcement was also designed to attack Lleida. Thereby, the Templars were given the charge of "defending Christianity" from their castle of Barberà by the Count of Urgell in 1132, which was located in the region.

113. Los Usatges de Barcelona...: 92 (number 73). However, there are examples of action by the Count and the King in line with this disposition. King Alfonso gave permission to the Abbot of Cuixà to fortify a town under his authority, Alfonso II. Rey de Aragón...: 215 (doc. No. 144) (1173), and other places, Alfonso II. Rey de Aragón...: 433-434 (doc. No. 325) (1181).

114. Els pergamins de l'Arxiu Comtal de Barcelona...: III, 1152 (doc. No. 1012) (1157).

115. García Fitz, Francisco. “Las prácticas guerreras"...: 335.

116. Diplomatari de Santa Maria de Poblet...: 88-89 (doc. No. 86) (1138), 93-94 (doc. No. 93) (1139) and 111 (doc. No. 118) (1149), respectively. The reconstruction of Bellcaire and Torre Fanega, Diplomatari de Santa Maria de Poblet...: 92-93 (doc. No. 92) and 97 (doc. No. 98), and a demolished castle in Penelles d'Algareix, Diplomatari de Santa Maria de Poblet...: 106-107 (doc. No. 111 ) (1147).

117. Els pergamins de l'Arxiu Comtal de Barcelona.... II, 871-2 (doc. No. 518) (1120) and Diplomatari de Santa Maria de Poblet...: 92-93 (doc. No. 92) (1139).

118. The watches, or the obligation of vigilance, were demanded in enfeoffments like Milmanda, Diplomatari de Santa Maria de Poblet...: $108-109$ (doc. No. 114) (1148 or 1149). In the enfeoffments of three castles, the lord demanded hosts and rides, Diplomatari de Santa Maria de Poblet...: $116-117$ (doc. No. 124) (1150). There was military tension in L'Espluga when a vassal was warned that if his lord habet guerram ipsum chastrum d'Espluga que adguent a gueregare, Diplomatari de Santa Maria de Poblet...: 123-124 (doc. No. 135) (1151). It was a seignourial war, although the lord understood that the castle needed reinforcement after the conquest of Siurana: et quando siat de cristianos Siurana faciatis vestra estatica ad ipsa Espluga. 
The Templars and Hospitallers were chosen with the aim of their developing military activity in the conquests and, significantly, in the domination of the occupied areas from imposing fortresses they obtained. From these, they defended the southern frontiers around the lower reaches of the Ebro. To give an idea, the military orders exercised their domain from the Suda of Tortosa, the castle of Gardeny in Lleida, and the fortresses of Amposta, Miravet, Ulldecona, Ascó and Horta, among others. The Count of Barcelona urged them to "ad propagandam sancte christianitatis fidem" and attacks the Muslim "infidels". ${ }^{119}$ Moreover, he involved the Templars and Hospitallers in the conflicts, to obtain booty and Muslims, who had to be captured on the raids. ${ }^{120}$ The orders became consolidated given their military skills against the Moors and, especially, in occupying their lands, which they did in the name of the county or royal authority.

From the mid $12^{\text {th }}$ century, there was a notable process of "castralisation" of the frontier lands, those occupied or re-feudalised and the conquered ones. The lords who led the occupation of regions like the Camp de Tarragona and the other conquered areas promoted the centralisation of power in a fortification or fortified place. There was a seigniorial push both to build fortifications and to reoccupy Andalusian castles and towers. In the Tarragona area, the beneficiaries of enfeoffed places where the population would gather were obliged to build fortifications. This happened in the enfeoffments of Mongons in 1149, Riudoms in 1151, where the lord would pay for half of the fortification, Cambrils in 1152, Salou in 1157, Albiol and Alforja in 1158, and also in Siurana in 1163, Rocabruna in 1171, or Picamoixons in $1171 .{ }^{121}$ In the conquered areas of Tortosa, Lleida and Siurana, the county and royal donations placed the fortifications at the centre of territorial domination, granted fundamentally to loyal people and the military orders. ${ }^{22}$

Castles were the focus of military domination, and by extension, the domain over the rural districts. Accordingly, they were also the main targets in power struggles. This is clearly seen in the judicial dispute between the Count of Barcelona and Pere de Puigvert in 1157 for various castles: Prenafeta, Piera and Barberà, or another

\footnotetext{
119. "Propagate the Christian faith". Other expressions reflected that it was a war without quarter, and that the Moorish enemies had to be destroyed, García, Francisco. “¿De exterminandis sarracenis? El trato dado al enemigo musulmán en el reino de Castilla-León durante la plena edad media" El cuerpo derrotado: cómo trataban musulmanes y cristianos a los enemigos vencidos, Maribel Fierro, Francisco García Fitz, eds. Madrid: Consejo Superior de Investigaciones Científicas, 2008: 113-166; especially 113.

120. Bonet, Maria. "Las órdenes militares en la expansión feudal de la corona de Aragón”. Anales de la Universidad de Alicante. Historia medieval, 17 (2011): 243-300, especially 255, 259-260 and 259-279.

121. Cartas de población y franquicia de Cataluña: 114-115 (doc. No. 70), 135-136 (doc. No. 84), 143 -144 (doc. No. 91), Diplomatari de Santa Maria de Poblet...: 169 (doc. No. 200), Cartas de población y franquicia de Cataluña: 161-162 (doc. No. 109), 162-163 (doc. No. 110), 175 (doc. No. 121) and 200-202 (doc. No. 140).

122. An example is the King Alfonso's concession of the fortifications of Tivissa, Mora, Garcia and Marçà to Guillem de Castellvell, member of a loyal family, Alfonso II. Rey de Aragón...: 261-262 (doc. No. 181), (1174).
} 
case between King Alfonso the Chaste and Ramon de Fonollar for the castles of Empúries and Fonollar in $1190 .{ }^{123}$

Only in certain areas did the Count or his son manage to exert domination through delegates of their direct authority in the castles. In this sense, resort was made to such figures as the castellan. This representative went from being the holder of castles to being the king's representative in the territory with certain military and political rank, that was different from the figure of the vassal or the seigniorial castellan himself. In the Siurana area, King Alfonso the Chaste opted to delegate his power to a castellan, Albert de Castellvell. As a government official, the castellan of Siurana participated in the granting of population charters in the more mountainous parts of the demarcation. ${ }^{124}$ This was specific situation in a region where the King asserted his rights of conquest against those theoretically acquired by the archbishop of Tarragona and exercised by other lords ${ }^{125}$ In the neighbouring area of the Conca de Barberà, the Count and his son, the King, faced the resistance of the local lineages and promoted the founding of localities or fiefs to limit this. Thus, King Alfonso promoted a population centre in Montblanc, under the authority of his bailiff for some time and then under the rule of the castellan. The castellany was made up of Montblanc and La Riba in 1176-8. ${ }^{126}$ The castellan held half the castle, although the king could use it and its dependencies militarily through the "hosting and the host". The figure of the castellan was consolidated as the king's representative with a specific military function, and the presence of this position spread to places that had other dominations. Thus, Alfonso the Chaste enfeoffed Conesa Castle to Ramon de Cervera, although he included his castellan in the concession and he also had to serve the king with his milites. ${ }^{127}$ An agreement between the Count of Urgell and the King in 1 187, established that et rex Aragon...mittat castlanum in predicta civitate Ilerde, as a way to exercise his power in the city. ${ }^{128}$

\section{Conclusions}

The concept of "war" was directly related to the defence or acquisition of patrimony, as seen recurrently in the documentation. The members of the aristocracy verbalised

123. Colección de documentos inéditos...: IV, 252-260 (doc. No. 99). Sometimes a "conveniencia" was established for setting rights to castles, in general in the king's favour in areas subjected to powerful lords, like against Guillem de Cervera, Alfonso II. Rey de Aragón...: 370-372 (doc. No. 276) (1179).

124. Cartas de población y franquicia de Cataluña: 175 (doc. No. 121) (1163), 186 (doc. No. 128) (1166), 189-190 (doc. No. 133) (1168), 196-198 (doc. No. 138) (1170), 199-200 (doc. No. 139) (1170).

125. Alfonso II. Rey de Aragón...: 218-220 (doc. No. 148) (1173).

126. Alfonso II. Rey de Aragón...: 288-290 (doc. No. 205) (1176), Diplomatari de Santa Maria de Poblet: 418 419 (doc. No. 571), and the previous provision of the office of bailiff, Alfonso II. Rey de Aragón...: 46-48 (doc. No. 12) (1163).

127. Alfonso II. Rey de Aragón...: 367-368 (doc. No. 272), (1178).

128. Alfonso II. Rey de Aragón...: 586-589 (doc. No. 443), and added: comes Urgel donet potestatem de predicta civitate Ilerde regi Aragon (1187). 
their commitment to fight for the lord's patrimony and to hold fiefs. Heritagisation, domination and fighting were concepts that could be assimilated to a single reality, and were even interchangeable. Thus, the term was especially identified with the defence of property in a more private sense than any other, and the expression "pacify" was applied to the restitution of seized property. In this context, the word "war" was used profusely to refer to the feudal war, the conflict par excellence in $12^{\text {th }}$ century Catalonia, although it was also applied to other larger military confrontations. In parallel, the participation of the different powers in the fortifications reflected that these were the focus of domination and regional war. This way, the castle was the target of intervention by the lordly powers, lords and vassals, and the axis of the military policies in the domain of territories, like those policies applied by the county or royal powers. These both intervened in the territories through the push for "castralisation" and to link the holders of the castles as vassals.

The Christian plans and attacks on al-Andalus went by specific names, like the reference to the intervention of divine providence in favour of Christianity, the facere exercitus (forming of an army) and others like capere (conquer), adquirere (acquire), liberare (liberate), and also guerram facere (make war). The language expressed the exceptional and special nature of these other conflicts, as shown by their being defined as supernatural. In this context, it should be noted that the Count of Barcelona, Ramon Berenguer III, participated in the first large-scale Catalan attack, together with the Pisans, while also sharing the leading position with the Count of Empúries. Yet, the Count of Barcelona stood out for that fact that he had an "army", paid some of these forces and, it seems, had some naval capacity before the middle of the $12^{\text {th }}$ century.

The Count of Barcelona's first plans for conquest included cooperation with some other count. However, these were replaced by projects that included the help of Italian contingents of specialised soldiers, like the military orders. In fact, he did not stand out in the military terrain until he managed to conquer Tortosa (1148), and he did so thanks to the special contributions of the Genoese, foreign fighters, the Templars and military techniques unknown until then in Catalonia, at least effectively and in combination, namely a navy and war machines. In this and subsequent operations, the Catalan aristocracy came under the military leadership of Ramon Berenguer IV, and to an extent, were relegated. Just one year later, the conquest of Lleida, which had been started by the County of Urgell, became another victory for the County of Barcelona, although with the participation and recognition of the rights of Urgell under his domain. Something similar happened with the conquest of the "wilāyah" of Siurana and which meant greater involvement of the Count of Barcelona in the region. The count had partially ousted the Count of Urgell, and clearly done the same to the lineages of the regions on the frontier of the newly-conquered lands, like the Anglesola, Cervera, and even the Puigvert families.

Shortly after the two most notable conquests of the mid- $12^{\text {th }}$ century, and in the county legislation, Ramon Berenguer IV granted himself the right over pax et guerra (the peace and the war), especially in relations with the Moors, and which King Alfonso the Chaste would renew. Both claimed this right in their domains and the areas under their influence, but ended up delegating this to their representatives. In 
contrast, this theoretical pre-eminent position in the administration of the "peace and the war" favoured agreements about military strategy in the Peninsula with other leaders on the same level. The Count and then the King derived a certain authority from war, and this helped to reinforce their political leadership in such questions as relations with the other leaders in the Peninsula, more direct intervention in the conquered areas and greater control over their relations with the aristocracy.

In fact, during the $12^{\text {th }}$ century, the aristocracy was reorganised and came under the leadership of important families in the region and the counts, like those of Barcelona or Urgell. The latter undertook various "pacifying" actions that meant the submission of the pacified nobles to their leadership, especially militarily, above all in the first half of the century. Moreover, by the second half of the century, the commitments to wage war on behalf of the lord had practically disappeared from the documents of enfeoffment. Significantly, the consolidation of the military and, partly, political leadership of the county of Barcelona derived from the exercise and control of the peace. The comital policies to achieve this pre-eminence varied, as did the agreements with the members of the nobility, which ranged from submission to their involvement in the great events. Furthermore, they dealt with ideological elements, like the crusading arguments, that contributed to the idea of a certain military specificity or specialisation and favoured the incorporation of new agents. The pacts with foreign allies were also important as these provided extra and extraordinary military powers over and above the local possibilities.

In $12^{\text {th }}$-century Catalonia, the feudal wars coexisted with other larger enterprises, like those of conquest. They both corresponded to distinct levels of domination, of a regional or supra-regional scope. The new supra-regional military demands favoured the protagonism of county or royal power, "pacification" and the incorporation of new actors, who irreversibly broke the exclusive aristocratic control of military domination. The great military change in the mid- $12^{\text {th }}$ century led to the move from wars for local private property to another style orientated towards "seizing" wide territories from the hands of the enemy. A military capacity and leadership became necessary, one that the feudal aristocracy was unable to offer due to its dynamics. Military efficiency, reached with new measures encouraged by the County of Barcelona, favoured the political consolidation of the Count at the head of a conglomerate of dominations, and over other aristocratic leaders who were very active until the mid century. Warfare was an essential demonstration of power, not so much as a derivation of politics, but more as a motor or stimulus of new social and political realities. However, attention to the various levels of military and political domination offers a complex image of $12^{\text {th }}$-century Catalan political history with a plural reality, which is a counterpoint to historiographic readings with statist and presentistic approaches. These approaches have resulted in narratives that have oversized the political entity of the power of the Count of Barcelona, offering an ascendant lineal image of the formation of a feudal "state". In fact, the struggle for private ownership and appropriation prevailed, but these wars actually favoured political developments aimed at achieving maximum efficiency and military domination. 